2007;370(9589):741-50. http://dx.doi.org/10.1016/S0140-6736(07)61377-4

3. Jones R. Can early diagnosis and effective management combat the irresistible rise of COPD? Br J Gen prac 2006;56(530):652-4.

4. British lung Foundation. Lost In Translation. 2006. BLF London.

5. National Clinical Guideline Centre. Chronic obstructive pulmonary disease: management of chronic obstructive pulmonary disease in adults in primary and secondary care. London: National Clinical Guideline Centre, 2010.

6. Global Strategy for the Diagnosis, Management and Prevention of COPD, Global Initiative for Chronic Obstructive Lung Disease (GOLD) 2013. Available from: http://www.goldcopd.org/.

7. Department of Health. An Outcomes Strategy for Chronic Obstructive Pulmonary Disease (COPD) and Asthma. Crown,London, 2011.

8. NHS Commissioning Board. The CCG Outcome Indicator Set 2013/14. 2012. Available from: http://www.commissioningboard.nhs.uk/files/2012/12/oisataglance.pdf

9. Falzon C, Soljak M , Elkin SL, Blake ID, Hopkinson NS. Finding the missing millions - the impact of a locally enhanced service for COPD on current and projected rates of diagnosis: a population-based prevalence study using interrupted time series analysis. Prim Care Respir J 2013;22(1):59-63. http://dx.doi.org/10.4104/ pcrj.2013.00008
10. Glasziou $P$, Buchan $H$, Del Mar $C$, et al. When financial incentives do more good than harm: a checklist. BMJ 2012;345:e5047. http://dx.doi.org/10.1136/ bmj.e5047

11. Woolhandler S, Ariely D, Himmelstein DU. Why pay for performance may be incompatible with quality improvement. BMJ 2012;345:e5015. http://dx.doi.org/ 10.1136/bmj.e5015

12. White P. Spirometric screening for COPD: wishful thinking, not evidence. Thorax 2007;62(8):742-3.

13. Levy ML, Quanjer PH, Booker R, Cooper BG, Holmes S, Small IR. Diagnostic spirometry in primary care: proposed standards for general practice compliant with American Thoracic Society and European Respiratory Society recommendations. Prim Care Resp J 2009;18(3):130-47. http://dx.doi.org/10.4104/pcrj.2009.00054

14. Parkes G, Greenhalgh T, Griffin M, Dent R. Effect on smoking quit rate of telling patients their lung age: the Step2quit randomised controlled trial. BMJ 2008; 336(7644): 598-600. http://dx.doi.org/10.1136/bmj.39503.582396.25

15. Gray M, El Trurabi A. Optimising the value of interventions for populations. BMJ 2012;345:e6192. http://dx.doi.org/10.1136/bmj.e6192

16. Hopkinson NS, Englebretsen C, Cooley N, et al. Designing and implementing a COPD discharge care bundle. Thorax 2011;67(1):90-92. http://dx. doi.org/10.1136/ thoraxjnl-2011-200233

\title{
The changing face of asthma in Finland: improved recognition and no further increase in symptoms
}

\section{See linked editorial by Kainu et al. on pg 64}

\section{*Anders Bjerg ${ }^{1}$}

1 (Post-doctoral) Researcher, Krefting Research Centre, Department of Internal Medicine and Clinical Nutrition, Sahlgrenska Academy, University of Gothenburg, Göteborg, Sweden

*Correspondence: Dr Anders Bjerg, Krefting Research Centre Göteborgs Universitet, Box 424, S-405 30 Göteborg, Sweden Tel: +46(0)707 604459 Fax: +46(0)31786 6730

E-mail: anders.bjerg@gu.se

Over the past half-century the prevalence of asthma and allergic conditions has increased considerably. The magnitude of this increase, as well as its seemingly global occurrence, has led to this being termed the "asthma epidemic". 'The supporting evidence is vast, ranging from symptom-based questionnaires to clinical evaluations and register studies of diagnoses and prescriptions. ${ }^{2}$

However, during the past decade, several studies (predominantly in children) have reported a levelling off of previously increasing trends. Famously, the International Study of Asthma and Allergy In Children (ISAAC) found no further increase of asthma in school-age children and teenagers in several regions. ${ }^{3}$ Other longitudinal crosssectional surveys of children recorded both the aforementioned rise in asthma and the recent plateau. In Aberdeen, Scotland, wheeze and shortness of breath increased considerably between 1964 and 1994 but not from 1994 to 1999. ${ }^{4}$ Similar trends were recorded from 1982 to 2002 in Belmont, Australia and were confirmed by methacholine bronchial responsiveness challenge. ${ }^{5}$
The Nordic countries also experienced a rise in asthma between the 1970's and 1990's in both children and adults. ${ }^{6,7}$ In northern Norway the prevalence of asthma symptoms increased in schoolchildren from 1985 to 1995, and then plateaued until 2000. ${ }^{7}$ In Sweden the prevalence of physician-diagnosed asthma and use of asthma medications increased slightly during the last two decades, both in schoolchildren ${ }^{8}$ and in adults..$^{9,10}$ However, in these studies, symptoms common to asthma were unchanged or even decreased in prevalence. The authors concluded that no real increase in asthma occurred after the 1990's, and that the rise in asthma diagnoses was explained by heightened awareness and changed healthcare practices. $^{8-10}$

This Nordic perspective is further extended to Finland by Kainu and colleagues in this issue of the PCRJ. ${ }^{11}$ Among adults living in Helsinki, the age-adjusted prevalence of physician-diagnosed asthma increased significantly from $6.5 \%$ to $10.0 \%$ ( $P<0.001)$ between 1996 and 2006, as did use of asthma medications (from 5.9\% to $9.2 \%$; $\mathrm{P}<0.001$ ). These upward trends were statistically significant after adjustment for differences in age, smoking and gender between the two populations. However, the same adjusted analyses showed no increase in the majority of symptoms common in asthma, most importantly recurrent wheeze and the "wheeze triad" (subjects experiencing wheeze with breathlessness apart from colds). The prevalence of allergic rhinoconjunctivitis increased from $37.2 \%$ to $44.4 \%$, whilst that of smoking decreased.

So, did asthma increase in Helsinki? It seems that despite a substantial increase in physician-diagnosed asthma, the prevalence of symptoms suggestive of asthma changed little in the population, similar to the recent findings in Sweden. ${ }^{8-10}$ Participation decreased from $76 \%$ to $62 \%$ in the Helsinki study, ${ }^{11}$ which unfortunately did not 
include any data on non-participants. However, it is unlikely that lower participation would have exerted different effects on trends in diagnoses and symptoms, respectively.

One possible explanation might be that increased use of asthma medications masked a real increase in more severe symptoms. Data on the prevalence of subjects using asthma medication and/or having asthma symptoms would have been helpful in this context. Clinically active asthma could thus be assessed in a similar way to the reporting of hypertension - which is commonly reported as a blood pressure measurement which may or may not fulfil hypertension management criteria, and whether or not the patient is on medication. ${ }^{12}$ In the two recent Swedish studies, ${ }^{8,9}$ no increases in asthma symptoms and/or medication use were reported after the 1990's, further supporting the notion that the rise in the number of asthma diagnoses did not reflect a true increase in clinically active asthma.

Another, more likely, explanation is increased diagnostic activity and awareness. Consequently, this may also reflect under-diagnosis prior to 1996. In 1996 the prevalence gap between asthma symptoms (e.g. shortness of breath or wheeze) and physician-diagnosed asthma was considerably larger in Helsinki, Finland than in Stockholm, Sweden. ${ }^{13}$ Following the significant increase in asthma diagnoses from 1996 to 2006 in Helsinki, this gap diminished by 2006. ${ }^{11}$ Among subjects with physician-diagnosed asthma, the proportion with asthma symptoms decreased from 1996 to 2006, similar to reports from Copenhagen, Denmark. ${ }^{14}$ This study by Kainu and colleagues ${ }^{11}$ adds further evidence that the nationwide Finnish Asthma Programme, implemented between 1994 and 2004, significantly improved recognition, diagnosis and treatment of the disease..$^{15}$ The proportion of patients diagnosed with asthma and using asthma medication was high, around $70 \%$, comparable to recent data from Stockholm, Sweden ${ }^{10},{ }^{16}$ and higher than in Copenhagen, Denmark. ${ }^{14}$

In light of previous studies, the present paper by Kainu et al. adds Finland to the list of Nordic countries where the trend in prevalence of asthma symptoms seems to have levelled off recently, whilst the prevalence of physician-diagnosed asthma continues to rise. ${ }^{7-11}$ It follows that "trends" in asthma, even within a defined geographic area, are not one but many things. Asthma is a multifaceted condition, and, as is so often the case in epidemiology, trends in prevalence become a matter of definition. Hitherto, repeated crosssectional surveys have been the preferred method of studying trends in asthma. Yet it is likely that repeated prospective studies would be far superior in this regard. Trends in incidence, remission and medication use could be studied simultaneously in clearly defined populations at risk, independent of cohort effects. Perhaps most importantly, trends in risk factors in relation to disease could also be studied. Several studies, including the present paper by Kainu and colleagues, ${ }^{11}$ have noted trends in risk factors such as smoking and rhinitis. ${ }^{7-10}$ However, how such trends in risk factors will affect trends in disease will remain - at least from analyses of cross-sectional data a guess at best.
Conflicts of interest The author declares that he has no conflicts of interest in relation to this article.

Commissioned article; not externally peer-reviewed; accepted 8th February 2013; online 21st February 2013

(C) 2013 Primary Care Respiratory Society UK. All rights reserved http://dx.doi.org/10.4104/pcrj.2013.00019 Prim Care Respir J 2013; 22(1): 13-14

\section{References}

1. Eder W, Ege MJ, von Mutius E. The Asthma Epidemic. N Engl J Med 2006; 355(21):2226-35. http://dx.doi.org/10.1056/NEJMra054308

2. Burney P. The changing prevalence of asthma? Thorax 2002;57(suppl 2):ii36-ii39.

3. Asher MI, Montefort S, Björkstén B, et al. Worldwide time trends in the prevalence of symptoms of asthma, allergic rhinoconjunctivitis, and eczema in childhood: ISAAC Phases One and Three repeat multicountry cross-sectional surveys. Lancet 2006;368(9537):733-43. http://dx.doi.org/10.1016/S0140-6736(06)69283-0

4. Devenny A, Wassall H, Ninan T, Omran M, Khan SD, Russell G. Respiratory symptoms and atopy in children in Aberdeen: questionnaire studies of a defined school population repeated over 35 years. BMJ 2004;329(7464):489-90. http://dx.doi.org/10.1136/bmj.38139.666447.F7

5. Toelle BG, Ng Man Kwong G, Belousova E, Salome CM, Peat JK, Marks GB. Prevalence of asthma and allergy in schoolchildren in Belmont, Australia: three cross sectional surveys over 20 years. BMJ 2004;328(7436):386-7. http://dx.doi.org/10.1136/bmj.328.7436.386

6. Åberg N, Hesselmar B, Åberg B, Eriksson B. Increase of asthma, allergic rhinitis and eczema in Swedish schoolchildren between 1979 and 1991. Clin Exp All 1995;25(9):815-19. http://dx.doi.org/10.1111/j.1365-2222.1995.tb00023.x

7. Selnes A, Nystad W, Bolle R, Lund E. Diverging prevalence trends of atopic disorders in Norwegian children. Results from three cross-sectional studies. Allergy 2005;60(7):894-9. http://dx.doi.org/10.1111/j.1398-9995.2005.00797.x

8. Bjerg A, Sandström T, Lundbäck B, Rönmark E. Time trends in asthma and wheeze in Swedish children 1996-2006: prevalence and risk factors by sex. Allergy 2010;65(1):48-55. http://dx.doi.org/10.1111/j.1398-9995.2009.02105.x

9. Bjerg A, Ekerljung L, Middelveld $R$, et al. Increased Prevalence of Symptoms of Rhinitis but Not of Asthma between 1990 and 2008 in Swedish Adults: Comparisons of the ECRHS and GA2LEN Surveys. PLOS ONE 2011;6(2):e16082. http://dx.doi.org/10.1371/journal.pone.0016082

10. Ekerljung L, Andersson A, Sundblad B, et al. Has the increase in the prevalence of asthma and respiratory symptoms reached a plateau in Stockholm, Sweden? Int J Tuberc Lung Dis 2010;14:764-71.

11. Kainu $A$, Pallasaho $P$, Piirilä $P$, Lindqvist $A$, Sovijärvi $A$, Pietinalho $A$. Increase in prevalence of physician-diagnosed asthma in Helsinki during the Finnish Asthma Programme: improved recognition of asthma in primary care? A cross-sectional cohort questionnaire study. Prim Care Respir J 2013;22(1):64-71. http://dx.doi.org/10.4104/pcrj.2013.00002

12. Lawes CMM, Hoorn SV, Rodgers A. Global burden of blood-pressure-related disease, 2001. Lancet 2008;371(9623):1513-18. http://dx.doi.org/10.1016/S01406736(08)60655-8

13. Pallasaho $P$, Lundback $B$, Meren $M$, et al. Prevalence and risk factors for asthma and chronic bronchitis in the capitals Helsinki, Stockholm, and Tallinn. Respir Med 2002;10:759-69. http://dx.doi.org/10.1053/rmed.2002.1308

14. Browatzki A, Ulrik CS, Lange P. Prevalence and severity of self-reported asthma in young adults, 1976-2004. Eur Respir J 2009;34(5):1046-51. http://dx.doi.org/ 10.1183/09031936.00177908

15. Haahtela $T$, Tuomisto $L E$, Pietinalho $A$, et al. A 10 year asthma programme in Finland: major change for the better. Thorax 2006;61(8):663-70. http://dx.doi.org/ 10.1136/thx.2005.055699 